Please cite this article as:

Dell'Era C, Landoni P and Verganti R (2015).

From Creative Individuals to Creative Capital: Value Creation and Appropriation Strategies of Creative Knowledge-Intensive Business Services.

International Journal of Innovation Management, Vol. 19, No. 2.

(DOI: 10.1142/S1363919615500164) 


\author{
Claudio DELL'ERA (Corresponding author) \\ Department of Management, Economics and Industrial Engineering, \\ Politecnico di Milano - Piazza L. da Vinci, 3220133 Milano Italy \\ Tel: +390223992798 \\ Fax: +3902 23994083 \\ claudio.dellera@polimi.it

\section{Paolo LANDONI} \\ Department of Management, Economics and Industrial Engineering, \\ Politecnico di Milano - Piazza L. da Vinci, 3220133 Milano Italy \\ Tel: +3902 23993973 \\ Fax: +390223994083 \\ paolo.landoni@polimi.it \\ Roberto VERGANTI \\ Department of Management, Economics and Industrial Engineering, \\ Politecnico di Milano - Piazza L. da Vinci, 3220133 Milano Italy \\ Tel: +390223992770 \\ Fax: +3902 23994083 \\ roberto.verganti@polimi.it
}

Keywords: Knowledge-Intensive Business Services, Creativity, Value Creation, Value Appropriation 


\section{FROM CREATIVE INDIVIDUALS TO CREATIVE CAPITAL: VALUE CREATION AND APPROPRIATION STRATEGIES OF CREATIVE KNOWLEDGE-INTENSIVE BUSINESS SERVICES}

\section{ABSTRACT}

In the increasingly knowledge-based economy, the role of the service sector, and in particular, of Knowledge Intensive Business Services (KIBS), is widely acknowledged. KIBS are considered "bridges of innovation". Furthermore, in addition to this pivotal role in supporting the competitiveness and development of other firms, KIBS sectors are, per se, increasingly relevant in terms of economic dimensions and employment. Creative KIBS span architecture, advertising, multimedia and internet applications, branding, design agencies, etc. and leverage creative processes and creative individuals. The importance of these firms is directly related to the increasingly acknowledged role of creativity and innovation for competitiveness.

In fact, while some KIBS have grown to significant sizes in the creative sector (e.g., IDEO and Continuum Innovation), normally, these firms fail to grow and consist of only the founding professionals and a limited number of close collaborators. As argued by Florida and Goodnight (2005), the company's most important asset is its creative capital and this is not just a collection of individuals' ideas, but a product of interaction. This paper relies on a sample of 8 Italian creative KIBS to analyze the value creation and appropriation strategies adopted by companies that were able to transform their creative capabilities from an individual asset to a company one (creative capital).

On the basis of a theoretical framework that is derived from the literature and based on three pillars (Unique Assets Development, Unique Assets and Unique Assets Value Appropriation), we identify several peculiar assets and strategies that are adopted by creative KIBS. Furthermore, we highlight the importance of Unique Asset Embodiment strategies, i.e., the importance of strategies for formalizing and codifying the unique assets in specific technologies, archives, processes and even products. We show that these strategies allow i) to 
extract more value from the already adopted value appropriation strategies and ii) to adopt specific strategies of value appropriation. 


\section{INTRODUCTION}

In the increasingly knowledge-based economy, the role of the service sector, and in particular, of Knowledge Intensive Business Services (KIBS), is widely acknowledged (e.g., Miles, 2007; Oke, 2007; NSF, 2010; Van Looy et al., 2011). Because of their focus on professional knowledge or expertise that is related to a specific technical or functional domain (Windrum and Tomlinson, 1999), KIBS are considered "bridges of innovation" (Czarnitzki and Spielkamp, 2000; Colombo et al., 2011). Furthermore, in addition to this pivotal role in supporting the competitiveness and development of other firms, KIBS sectors are, per se, increasingly relevant in terms of economic dimensions and employment. KIBS encompass services in growing industries, such as management consultancy (including financial, legal, accounting and marketing), design consultancy, advertising, technical engineering, Information and Communication Technologies (ICT) services and software, training and environmental services (for a discussion of the different KIBS typologies, see, for instance, Muller and Zenker, 2001).

A particularly interesting and less explored subsector of KIBS is the creative KIBS subsector. Creative KIBS span architecture, advertising, multimedia and internet applications, branding, design agencies, etc. and leverage creative processes and creative individuals. The importance of these firms is directly related to the increasingly acknowledged role of creativity and innovation in competitiveness (see, for instance, European Commission, 2010). Recent studies have underlined the importance of external designers in the innovation process to the point that some of these designers are considered "superstars", such as Jacob Jensen and David Lewis for Bang \& Olufsen, Michael Graves for Target, and Jonhatan Ive for Apple (Ravasi and Lojacono, 2005; Durgee, 2006; Dell'Era and Verganti, 2010).

Very often the competitive performances of the creative KIBS are strictly connected to the capability shown by individuals (usually the founder(s) and a limited number of close 
collaborators) that represents the main capital of the firm. Only few KIBS (e.g., IDEO and Continuum Innovation), have demonstrated the capability to build a creative capital that allows to move from a business model based on few high-skilled individuals to one based on firm assets and resources. As argued by Florida and Goodnight (2005), the company's most important asset is its creative capital and this is not just a collection of individuals' ideas, but a product of interaction. In this work, focusing on firms that operate in the creative KIBS subsector, we aim at identifying and analyzing the managerial practices adopted by companies characterized by a creative capital. More specifically we aim at investigating the value creation and appropriation strategies adopted by companies that were able to transform their creative capabilities from an individual asset to a company one (creative capital).

The paper is organized as follows: in the next section, the theoretical framework, and in particular, the literature that addresses value creation and appropriation strategies, is presented; in Section 3, the research design and the empirical setting are illustrated; Sections 4 and 5 present the case studies and the results, considering the value creation and appropriation strategies that are adopted; Section 6 concludes with a discussion of the results, the limits of the research and avenues for future studies.

\section{THEORETICAL FRAMEWORK}

Knowledge intensity, weak intellectual property protection and the importance of strong, close relationships with clients (e.g., Starbuck, 1992; Muller and Zenker, 2001; Oke, 2007) represent peculiar characteristics of the KIBS; they require ad hoc practices in order to valorize the potentialities provided by creative individuals and transform them in assets and resources that can be exploited by the entire organization. As previously mentioned, very often these firms are built around the reputation and the skills of their founder(s) to the point that they adopt the name of the founder(s) as their formal name (e.g., McKinsey, Ernst \& 
Young). For this reason, KIBS continuously look for new creative talents. At the same time, in order to succeed, they should try to formalize and codify the processes and knowledge in order to create creative capital that can be exploited by the entire organization.

Florida and Goodnight (2005) underline that the creative capital of a company goes beyond the "collection" of creative individuals and ideas, it encompasses the managerial practices they adopt and the interactions developed between the individuals. They highlight three managerial principles to strengthen a firm creative capital: help creative employees keeping them intellectually engaged and removing distractions, make managers responsible for sparking creativity in all employees and engage customers as creative partners. In this work we complement and expand the research on the determinants of creative capital on the basis of a theoretical framework that is derived from the resource-based view literature (e.g., Penrose 1959; Wernerfelt, 1984; Barney, 1991). In particular, we consider the competitiveness of KIBS as strictly connected to the presence and exploitation of a series of Unique Assets (values). Penrose's (1959) seminal contributions have highlighted the direct link between the competitiveness of a firm and its human and managerial resources. Wernerfelt (1984) notes that strategic resources are the resources that are strictly related to the firm and that can lead to sustainable competitive advantages, such as brands, technological knowledge, skilled personnel, trade contracts and efficient procedures. Barney (1986) classifies these resources into three main categories: physical capital resources, which also include technologies; human capital resources, which also include experience and knowledge; and organizational capital resources.

Human capital resources (Starbuck, 1992) and organizational capital resources (Werr and Stjernberg, 2003) have been considered especially relevant to the explanations for KIBS' competitiveness. This relevance is especially due to the simultaneity of production and consumption and the intangible nature of the service, which transforms the provider-customer interface into both a locus and a source of innovation (Gadrey and Gallouj, 1998). The 
authors in this stream of theory identify a number of prerequisites for these strategic resources; for instance, they suggest that the resources must be heterogeneous, immobile, valuable, rare and imperfectly imitable. The specific forms that these strategic resources assume in creative KIBS have been explored less in the literature. Thus, one of the focus of our work is the identification of the strategies that are adopted by creative KIBS to create their Unique Assets (values). In addition to our analysis of the strategies that are implemented by creative KIBS to develop these assets and create value (Unique Asset Development) we analyze how they exploit such assets and appropriate the value (Unique Assets Value Appropriation) taking into account their peculiarities, and in particular, their knowledge intensiveness (Muller and Zenker, 2001). In fact the creation of strategic assets is not enough to obtain and maintain a competitive position in the market; strategies of value appropriation are pivotal in the transformation of value in effective results and the maintenance of these results over time (Mizik and Jacobson, 2003; Lepak, Smith and Taylor, 2007). For instance, Teece (1986) underlines the importance of developing complementary assets (such as manufacturing capacities for firms that are developing technological innovations). Within this perspective, some authors underline the importance of exploitation strategies rather than exploration strategies. Exploitation strategies include pivotal activities, such as selection, planning, production, implementation and execution (March 1991), and in professional Service Firms, the analysis of efficiency, efficacy and profitability (Groysberg and Lee, 2009).

Specifically we consider a theoretical framework based on three pillars: Unique Assets Development, Unique Assets and Unique Assets Value Appropriation. The first two pillars (Unique Assets Development and Unique Assets) are related to value creation processes, while the last pillar (Unique Assets Value Appropriation) is linked to value appropriation strategies (Figure 1Errore. L'origine riferimento non è stata trovata.). 


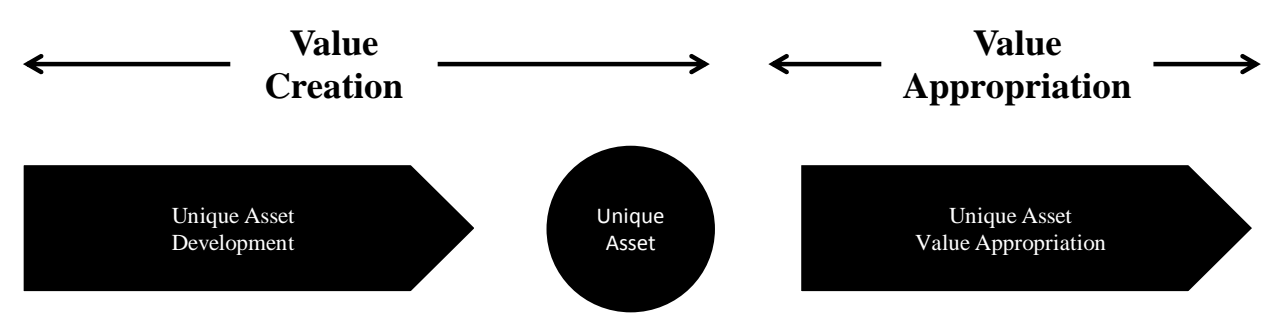

Figure 1: Theoretical framework

To summarize, through the in-depth analysis of 8 case studies, our work is aimed at identifying and analyzing strategies for value (Unique Asset) creation and appropriation adopted by creative KIBS that were able to transform their creative capabilities from an individual asset to a company one (creative capital).

\section{RESEARCH DESIGN AND EMPIRICAL SETTING}

Due to the complex system of variables that characterize the problem, we use a case study methodology approach, which allows us to develop a holistic and contextualized analysis. This method aligns with the exploratory nature of the research, as it allows us to not only explore the phenomenon in its complexity but also identify the critical variables (Eisenhardt and Graebner, 2007). Therefore, our case studies have an exploratory intent and are retrospective and multiple in nature (Yin, 1984). To gather empirical evidence for each creative KIBS company, we carried out two in-depth interviews and a brief questionnaire, which was useful for collecting background data that encompassed turnover, employees, client portfolios, typologies of projects, and project tools. Both interviews were planned according to a protocol that was meant to investigate the strategies adopted by the creative KIBS. The first interview was organized with the CEO or the owner (very often, also the founder) of the company, while the second interview was conducted with one of the key 
design managers. All interviews were carried out by at least two authors. Before starting the data analysis phase, we retrieved additional information through secondary resources for data triangulation purposes. Each author developed the content analysis and coded the principal phases of the innovation process (Eisenhardt, 1989). To increase the robustness of the interpretations, the authors' interpretations were tested by re-contacting the interviewees by phone, and reports of each case study were shared with the interviewees to obtain final approval.

As previously mentioned, the paper relies on a sample that comprises 8 Italian creative KIBS that were selected according to the following criteria:

- Foundation year before 2000. The possibility to observe more than one decade of evolution allows us to understand the different practices adopted by the creative KIBS moving from a strategy based on few highly-skilled individuals to one based on firm assets and resources (creative capital);

- More than 20 employees. The companies should have reached a significant dimension that require the implementation of formalized and structured practices aimed at exploiting the creative capital.

As shown in Table 1, the Italian creative KIBS case studies present significant differences in terms of client typologies and size. If Antonio Citterio Patricia Viel and Partners and Studio Marco Piva mainly operate in the architecture industry, then Design Group Italia, Design Innovation and Makio Hasuike and Co. provide mainly product design services. Therefore, the first two creative KIBS interpret product design activities as an extension of their reflections on architectural projects; for this reason, they concentrate their effort on specific product categories, such as furniture and lighting. By contrast, Design Group Italia, Design Innovation and Makio Hasuike and Co. collaborate with clients that operate in different industries (automotive, food, consumer electronics, etc.). Laura Polinoro Workshop (LPWK) was established by Alessi in 1998 in order to directly exploit its creative assets by supporting 
other companies in scouting appropriate designers and providing design services. Alessi is a leading Italian kitchenware manufacturer that collaborates with more than 200 designers, a network that has been built over decades. Future Concept Lab is a research institute that specializes in identifying emerging lifestyles and socio-cultural evolutions; specifically, it provides services that are aimed at developing new scenarios, and consequently, it does not show any type of specialization in terms of industry. Finally, Italdesign Giugiaro started providing product style services in the automotive industry, but throughout its history, has enriched its portfolio by adding engineering, modeling, prototyping and testing services. The number of employees and project-based collaborators in 2009 ranges from 14 (Design Innovation) to 900 (Italdesign Giugiaro), while the annual turnover in 2009 ranges from 0.35 mln $€$ (Design Innovation) to $120 \mathrm{mln} €$ (Italdesign Giugiaro). The variety in the sample allows us to investigate and analyze the complexity of the research problem; specifically, it allows us to identify the various value creation and appropriation strategies adopted by creative KIBS in order to exploit the creative capital. At the same time, the focus only on Italian creative KIBS that operate in the design and architecture fields reduces the complexity of the analyses. In fact, this choice allows to highlight the role of value creation and appropriation strategies limiting the impact of sector specificities and country specificities in the interpretation of the results. 


\begin{tabular}{|c|c|c|c|c|}
\hline Creative KIBS & Foundation year & $\begin{array}{l}\text { Number of } \\
\text { employees and } \\
\text { project-based } \\
\text { collaborators } \\
(2009) \\
\text { (approx) }\end{array}$ & $\begin{array}{l}\text { Turnover } \\
(2009), \\
\text { thousands of } € \\
\text { (approx) }\end{array}$ & Description \\
\hline $\begin{array}{l}\text { Laura Polinoro Workshop (LPWK) } \\
\text { [www.laurapolinoro.com] }\end{array}$ & 1998 & 20 & 1,000 & $\begin{array}{l}\text { Alessi, one of the most important "Factories of Italian Design", is based in Crusinallo, a region that is } \\
\text { historically devoted to household goods production; since the 1950s, Alessi has specialized in stainless steel } \\
\text { manufacturing. Centro Studi Alessi (CSA) was conceived at the end of the 1980s from an idea that was } \\
\text { developed by Alberto Alessi, Alessandro Mendini and Laura Polinoro, who was called to develop the initial idea } \\
\text { for creating a research center to integrate and innovate Alessi's established project system. Since 1998, the CSA } \\
\text { no longer exists as a physical entity, as its identity has transmogrified into a freer, more virtual realm of design } \\
\text { research and contact with the world of emerging international design and is run by Laura Polinaro as an } \\
\text { independent consultant. In the opening years of the new millennium, Laura set up a network of residential } \\
\text { workshops that take place largely in Italy, and some of the resulting projects have gone into production with the } \\
\text { acronym "LPWK" next to the name of the designer. }\end{array}$ \\
\hline $\begin{array}{l}\text { Antonio Citterio Patricia Viel and Partners } \\
\text { [www.antoniocitterioandpartners.it] }\end{array}$ & 1999 & 60 & 10,000 & $\begin{array}{l}\text { Founded by Antonio Citterio and Patricial Viel in 1999. Antonio Citterio opened his studio, where he started his } \\
\text { architectural and interior design business, in } 1972 \text {. Between } 1987 \text { and 1996, he worked in association with Terry } \\
\text { Dwan, and together, they created buildings in Europe and Japan. Among his most significant works are the } \\
\text { restyling of a block in the historical centre of Seregno; the Esprit headquarters in Amsterdam, Antwerp and } \\
\text { Milan; industrial plants for Vitra in Germany, and for Antonio Fusco in Milan. In 2000, Antonio Citterio and } \\
\text { Patricial Viel founded a second studio in Hamburg. }\end{array}$ \\
\hline $\begin{array}{l}\text { Design Group Italia } \\
\text { [www.designgroupitalia.com] }\end{array}$ & 1968 & 30 & 1,500 & $\begin{array}{l}\text { Founded by Marco Del Corno, Design Group Italia is managed by } 4 \text { partners: Edgardo Angelini, Ross De } \\
\text { Salvo, Peter Newbould, and Sigurdur Thorsteinsson. The quality of Design Group Italia's contribution to every } \\
\text { stage is based on the ability to bring together marketing, communication and technological considerations to } \\
\text { formulate a good idea. Based in the design hub of Milan since the 1960s, Design Group Italia has gained much } \\
\text { experience in and knowledge of understanding emerging consumer trends and styles across diverse market } \\
\text { sectors. }\end{array}$ \\
\hline $\begin{array}{l}\text { Design Innovation } \\
\text { [www.designinnovation.net] }\end{array}$ & 1997 & 25 & 300 & $\begin{array}{l}\text { Design Innovation, which was established and directed by Carmelo Di Bartolo and Pino Molina Betancor, } \\
\text { applies the experience that has been acquired over more than twenty years of co-ordinating the requirements of } \\
\text { design, production, training, communications and the market for industry and public administrations. Design } \\
\text { Innovation works by establishing interdisciplinary groups in which designers, architects, engineers, economists } \\
\text { and experts in buildings consumption scenarios and models team up with managers, corporate executives and } \\
\text { technicians to develop future scenarios and designs. Design Innovation is certificated with ISO 9001:2000. }\end{array}$ \\
\hline
\end{tabular}




\begin{tabular}{|c|c|c|c|c|}
\hline $\begin{array}{l}\text { Future Concept Lab } \\
\text { [www.futureconceptlab.com] }\end{array}$ & 1989 & 25 & 1,500 & $\begin{array}{l}\text { Future Concept Lab is a research Institute that stands out in the international landscape as } \\
\text { one of the most advanced research centers that specializes in marketing issues and trends in } \\
\text { consumption. It is headquartered in Milan and in January 2011, opened a new office in São } \\
\text { Paulo (Brasil). Future Concept Lab has correspondents in twenty-five countries around the } \\
\text { world, and these international relationships are made evident by the existence of a virtual } \\
\text { platform: the Genius Loci Lab. Future Concept Lab's goal is to develop and share new } \\
\text { concepts regarding products, communication and distribution to enable its clients to } \\
\text { effectively handle both advanced and emerging markets and work in terms of the key words } \\
\text { of the future. The Institute implements integrated research projects that are based on } \\
\text { specific methodologies that lead to the definition of sector-related scenarios, offers } \\
\text { consultancy and training services, and publishes works that represent the Institute's main } \\
\text { activities, internationally and internally. }\end{array}$ \\
\hline $\begin{array}{l}\text { Italdesign Giugiaro } \\
\text { [www.italdesign.it] }\end{array}$ & 1968 & 900 & 120,000 & $\begin{array}{l}\text { On } 13 \text { February 1968, Italdesign of Turin was founded under the original name of Studi } \\
\text { Italiani Realizzazione Prototipi S.p.A. The company was founded and developed by two } \\
\text { Piedmont families, the Giugiaros and the Mantovanis, and since its creation, has spanned } \\
\text { two generations. Theirs was an innovative formula for the automobile industry: the creation } \\
\text { of a services company for the large multinationals that operated in the sector and the } \\
\text { intuition of a young designer and a proven architect regarding the future trends in the } \\
\text { automobile market, which involved outsourcing by the great carmakers of the entire design } \\
\text { of a vehicle or phases of the new vehicle development process with the intention of } \\
\text { expanding the range of products in a short time; this approach substantially reduces the } \\
\text { 'time to market' of new models. In May 2010, Volkswagen AG subsidiary Lamborghini } \\
\text { Holding S.p.A acquired } 90.1 \% \text { of Italdesign-Giugiaro S.p.A shares, including the brand } \\
\text { name rights and patents. Italdesign Giugiaro's mission is to provide a wide variety of } \\
\text { services, ranging from creativity to engineering, validation and prototyping and to } \\
\text { industrialize new vehicles and products. From rational conception to the real object. }\end{array}$ \\
\hline $\begin{array}{l}\text { Makio Hasuike \& Co. } \\
\text { [www.makiohasuike.com] }\end{array}$ & 1968 & 25 & $\begin{array}{l}3,000 \\
(1,700 \text { from MH } \\
\text { Way) }\end{array}$ & $\begin{array}{l}\text { Born in Tokyo in 1938, Makio Hasuike completed a degree in Industrial Design from } \\
\text { Tokyo University of the Arts in } 1962 \text {. He started his career in Japan as a designer at Seiko, } \\
\text { where he worked on the designs for a series of watches and timers for the } 1964 \text { Tokyo } \\
\text { Olympic Games. He has resided in Italy since } 1963 \text { and operated in various sectors within } \\
\text { the design industry. In 1968, he set up his own practice in Milan. In 1982, he decided to } \\
\text { undertake an experimental project and conceived and released onto the market a series of } \\
\text { innovative products - including new types of briefcases - and in the process, gave rise to } \\
\text { MH Way. His wide-ranging design work allows him to be directly involved with aspects } \\
\text { that relate to manufacturing and distribution. The company, which is still in business today, } \\
\text { is a rare example of a truly successful design company. Hasuike's designs have been } \\
\text { showered with prestigious awards and have been included in permanent exhibitions that are } \\
\text { staged in numerous museums around the world. }\end{array}$ \\
\hline $\begin{array}{l}\text { Studio Marco Piva } \\
\text { [www.studiomarcopiva.com] }\end{array}$ & 1984 & 35 & 1,500 & $\begin{array}{l}\text { Marco Piva is an Italian architect and designer. In 1984, Studio Marco Piva opened and } \\
\text { carried out activities that ranged from large architectural projects for tourist facilities to } \\
\text { interior design, and finally, industrial design for the production of accessories for common } \\
\text { areas. In 1987, Marco Piva also founded IDA, International Design Agency, an Italian } \\
\text { interface for a World Design Network system. In 2001, a variety of experiences in strategic } \\
\text { consulting in the field of design and hotel contract work culminated in consulting work with } \\
\text { the contract division Federlegno - Arredo. }\end{array}$ \\
\hline
\end{tabular}

Table 1: Creative KIBS 


\section{VALUE CREATION AND APPROPRIATION STRATEGIES}

As previously mentioned, the first objective of the research is to investigate the strategies that are adopted by creative KIBS to create and appropriate value. Specifically, we analyzed eight Italian creative KIBS to develop a taxonomy that is based on the three pillars introduced in the literature-based theoretical framework: Unique Asset Development, Unique Asset and Unique Assets Value Appropriation (Figure 1). To develop the taxonomy we recoded the results obtained in the interviews and from secondary sources; in particular we analyzed all collected materials referring to each one of the three pillars. For each pillar we tried to categorize the actions and the strategies enacted by the analyzed firms considering similarities and differences among our case studies and theories already mentioned in the literature review. The main result of the coding process is reported in Figure 2 and further detailed in the following paragraphs.

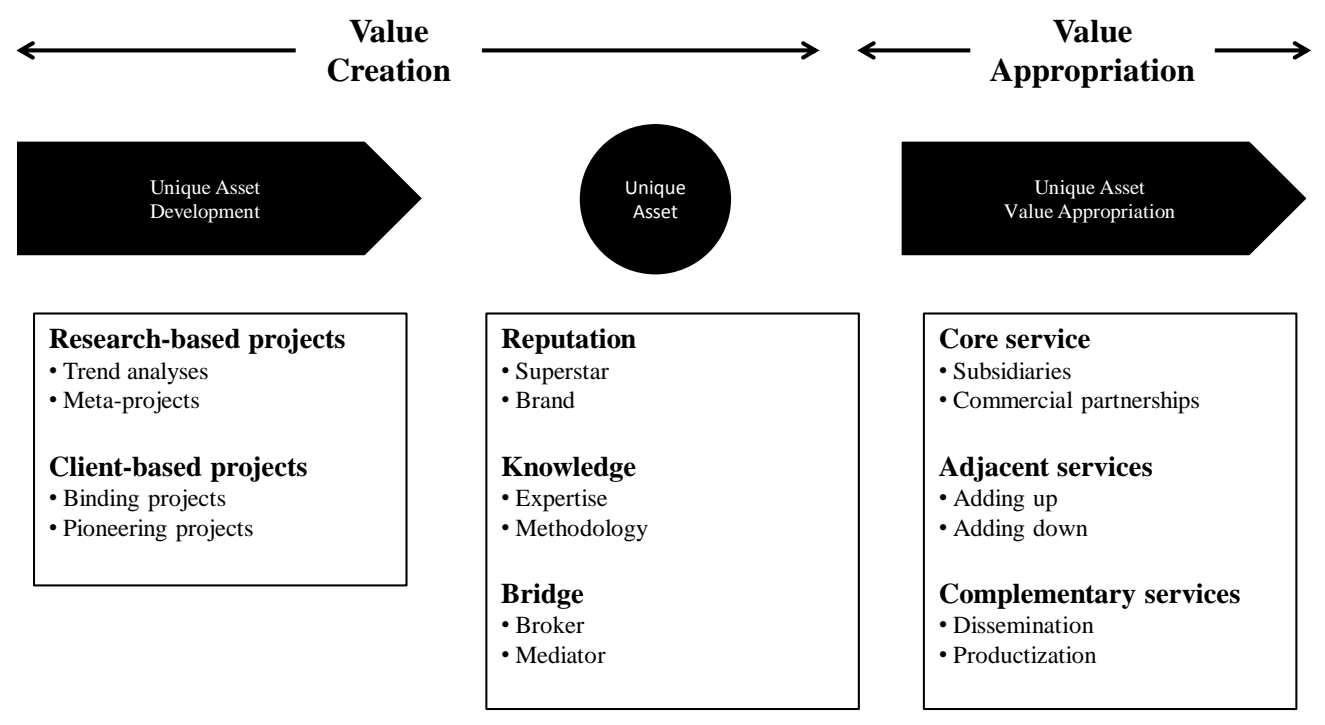

Figure 2: Taxonomy of value creation and appropriation strategies adopted by creative KIBS 


\subsection{Value creation strategies}

\section{$\underline{\text { Unique Asset Development }}$}

The analysis of the eight Italian creative KIBS underlines two basic strategies that are adopted to develop new unique assets. Some companies generate distinctive resources and skills through dedicated projects whose aim is expressly the creation of new assets. These projects do not represent the answers to briefs that are proposed by clients, but they are the results of ad hoc investments and take inspiration from intuition and reflections that are developed internally by creative KIBS (Research-based projects). Other companies exploit the opportunities that come from collaborations with clients to generate new assets; they develop Client-based projects not only to solve clients' proposed briefs but also to create new distinctive capabilities and competences (see Table 2).

More specifically, Research-based projects can be implemented with two alternative approaches: while Trend analyses foresee the identification of new opportunities that come from the market or emerging phenomena in consumer behaviors, Meta-projects are directed toward the development of new scenarios, which involve possible future evolutions of current markets. In other words, the first approach requires mainly analytic attitudes and is based on scouting and forecasting activities, while the second approach leverages design capabilities because it does not rely on historical data and does not involve an expectation that past observations will still be valid in the future. As argued by Dell'Era et al. (2008), Meta-projects are characterized by scenario development activities because they are directed toward the envisioning of new experiences and product lines rather than the satisfaction of explicit needs through single solutions. Considering the absence of specific clients, "evocative" (see Table 2) projects can be interpreted as Meta-projects; their nature is explorative because they have fewer constraints to consider, for the same reason that they are more radical in comparison with "traditional" projects. At the same time, they are significantly different from Trend analyses because they are directed toward the development of new scenarios and concepts, 
and consequently, they foresee the realization of preliminary embodiments of future products and services (sketches, storyboards, prototypes, etc.).

The second Unique Asset Development category (Client-based projects) also has alternative approaches: while Binding projects are sets of projects with which one is able to generate new and unique assets because of their relevant synergies and common elements, Pioneering projects can be defined as experimental projects in which unconventional temporary partnerships between stakeholders from different industries join together in the development of new market applications. On the one hand, the approach that is based on Binding projects increases creative KIBS' efficiency through the interpretation of "traditional projects" as sources of new knowledge and skills, and on the other hand, they allow for the management of contract projects, for which the capability to propose holistic solutions is particularly appreciated. Pioneering Projects are normally a collaboration between several valuable partners (e.g., architects, engineers and construction companies), who interpret new meanings of the future scenario. Therefore, Pioneering Projects are unique opportunities to create and develop new knowledge (Verganti, 2009). Considering that clients of Pioneering Projects agree to face new avenues and to create new landmarks, they provide more freedom to explore radical solutions. Moreover, Pioneering Projects represent the opportunity of sharing and developing new knowledge with noncompeting interpreters who are at the forefront of research and exploration. The value of such projects is strongly influenced by the explorative attitude that is demonstrated by involved partners. Innovators can use products in special settings outside the normal market stream, where they have greater freedom to explore new solutions; moreover, clients of such projects are more prone to delve into new avenues and create new landmarks. 


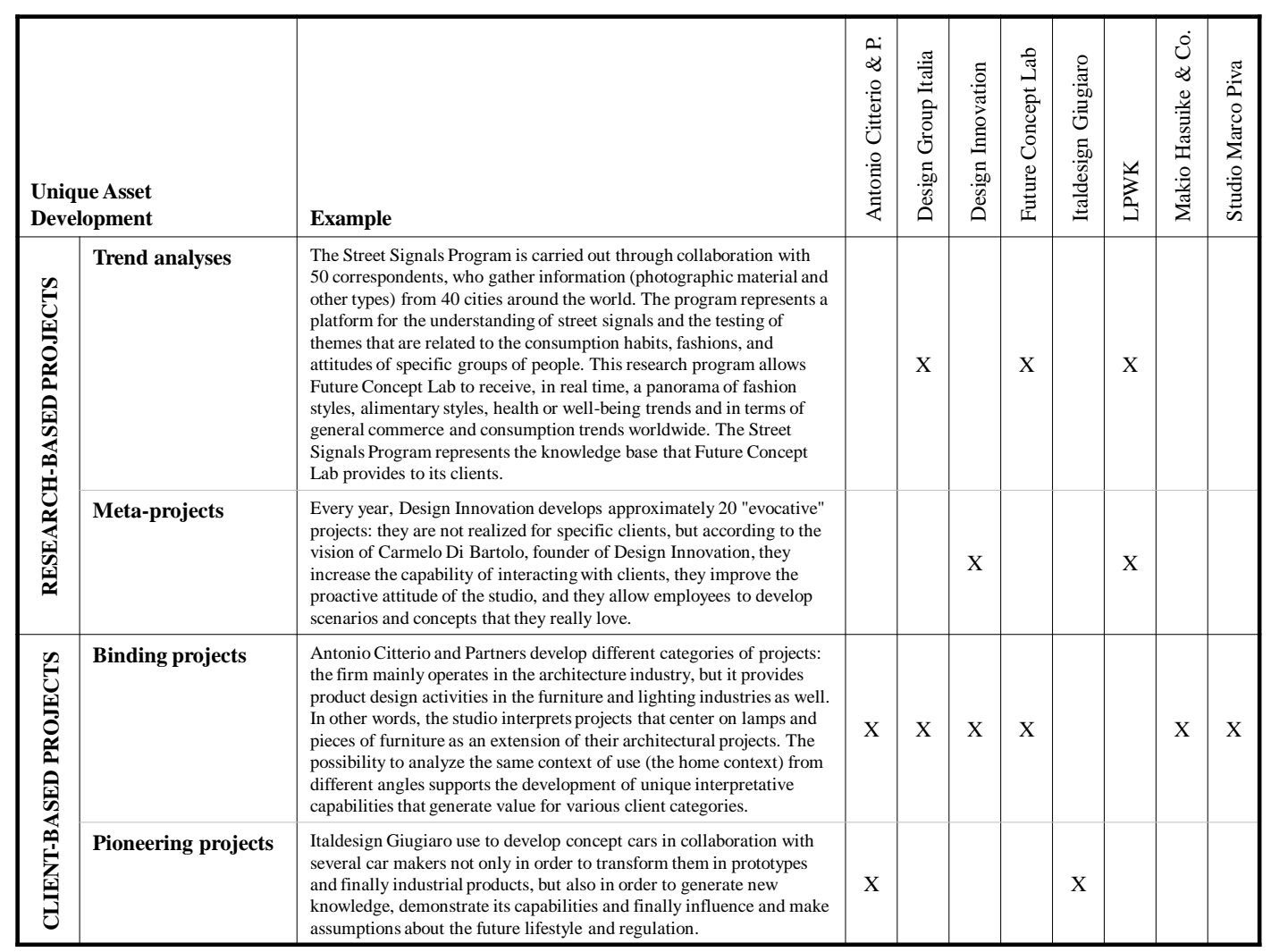

Table 2: Examples of Unique Asset Development strategies

\section{$\underline{\text { Unique Asset }}$}

As previously mentioned, seminal works on the resource-based view (RBV) explain how companies can gain sustainable competitive advantage through resource analysis, which is the core of design and the implementation of appropriate strategy. Several classification systems have been proposed in this literature stream. For example, Barney (1991) introduces three main categories: physical capital resources (including technologies, plants and equipment that are used in a firm, the firm's geographical location and the firm's access to raw materials), human capital resources (including experience, training, and relationships) and organizational capital resources (including formal and informal planning and controlling and coordinating systems). If physical capital resources are particularly relevant in manufacturing industries, then the other two categories also represent key assets for KIBS. Especially in the case of KIBS, human capital resources can be interpreted as carriers of individual expertise (Starbuck, 1992) to the point that, very often, the name of a company reflects the name of the 
company's founder(s). In other words, one of the Unique Assets that creative KIBS can leverage to compete at the international level is the Reputation that they are able to build and communicate around the world: four of the eight case studies explicitly leverage the Superstar status of their founders (Antonio Citterio Patricia Viel and Partners, Italdesign Giugiaro, Makio Hasuike \& Co., and Studio Marco Piva). By adopting the names of their founders, creative KIBS make a risky decision: few creative KIBS are shifting their strategy from a business model that is based on superstars to a business model that is based on teams and organizations that valorize the company Brand (e.g., Future Concept Lab).

If human resources are crucial in the development of creative KIBS, KIBS need to freeze and codify knowledge into the organization and transform it into organizational routines and culture. The development of methodologies and case histories is directed toward the transfer of tacit knowledge and experiences so that the firm can be useful and effective in the delivery of services for new clients. Specifically, the Knowledge Unique Asset has two typologies in our sample: the asset can involve Expertise, which is interpreted as a set of competences, or Methodology, which is interpreted as specific processes and tools that support design activity. 


\begin{tabular}{|c|c|c|c|c|c|c|c|c|c|c|}
\hline \multicolumn{2}{|c|}{ Unique Asset } & Example & 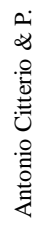 & 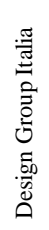 & 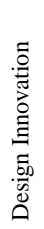 & 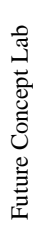 & 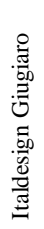 & $\frac{1}{3}$ & 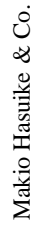 & 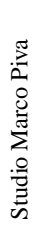 \\
\hline \multirow{2}{*}{ 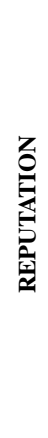 } & Superstar & $\begin{array}{l}\text { Antonio Citterio graduated with a degree in architecture from the } \\
\text { Politecnico di Milano, and since 1972, has worked for many leading } \\
\text { furniture manufacturers. He has won many prizes, including the } \\
\text { prestigious Compasso d'Oro in } 1987 \text { and 1995; his products are part of } \\
\text { the MoMA permanent collection and the Centre_Georges-Pompidou in } \\
\text { Paris. Giorgetto Giugiaro (born } 7 \text { August 1938) is an Italian } \\
\text { automobile designer who is equally responsible for a stable of } \\
\text { supercars and several of the most popular everyday vehicles driven } \\
\text { today; he was named Car Designer of the Century } 1999 \text { and inducted } \\
\text { into the Automotive Hall of Fame in 2002. }\end{array}$ & $\mathrm{X}$ & & & & $\mathrm{X}$ & & $\mathrm{X}$ & $\mathrm{X}$ \\
\hline & Brand & $\begin{array}{l}\text { With extensive research activities in Europe, North America, South } \\
\text { America and Asia, Future Concept lab was born as a global project. } \\
\text { Established in } 1989 \text { by Francesco Morace, the research institute } \\
\text { collaborates with companies in several countries. Future Concept Lab } \\
\text { has been recognized as one of the most complete research laboratories } \\
\text { in the world in terms of handling questions regarding consumption and } \\
\text { innovative concepts. }\end{array}$ & & & & $\mathrm{X}$ & & & & \\
\hline \multirow[b]{2}{*}{ 采 } & Expertise & $\begin{array}{l}\text { Studio Marco Piva was able to enter the contract projects (hotel, retail, } \\
\text { etc.) market and gain a leading position in comparison with other } \\
\text { architectural studios through the development of advanced capabilities } \\
\text { in the project management field. This specific expertise allows Studio } \\
\text { Marco Piva to fill the role of main contractor and coordinate several } \\
\text { other partners. }\end{array}$ & $\mathrm{X}$ & & & & & $\mathrm{X}$ & $\mathrm{X}$ & $\mathrm{X}$ \\
\hline & Methodology & $\begin{array}{l}\text { Design Group Italia bases its value proposition on the process that they } \\
\text { adopt during collaboration with every client; specifically, they advance } \\
\text { through the following three main phases: } \\
\text { - Orientation: through an understanding of the competitive } \\
\text { landscape, consumer life-styles, and emerging trends, they help } \\
\text { their clients identify a tailor-made roadmap for innovation; } \\
\text { - Creation: the production process that is appropriate for the } \\
\text { client's means and the knowledge that was gained during } \\
\text { Orientation create a strong foundation for exploration of the } \\
\text { new concepts; } \\
\text { Implementation: once concepts are to be implemented, Design } \\
\text { Group Italia continues to help the design's progression by } \\
\text { supporting on both a technical and brand level and ensuring that } \\
\text { an optimum experience is delivered. }\end{array}$ & & $\mathrm{X}$ & $\mathrm{X}$ & & $\mathrm{X}$ & & & \\
\hline \multirow[t]{2}{*}{$\begin{array}{l}\text { 窇 } \\
\text { 总 }\end{array}$} & Broker & $\begin{array}{l}\text { Future Concept Lab is able to intercept emerging phenomena around } \\
\text { the world through collaboration with } 50 \text { cult searches that are } \\
\text { distributed in the principal cities of the world and periodically collect } \\
\text { and report various categories of material (pictures, notes, sketches, } \\
\text { etc.). The research institute compares, analyze and synthesizes bits of } \\
\text { knowledge from different countries to provide a holistic view of socio- } \\
\text { cultural trends and new lifestyles. In other words, the network of cult } \\
\text { researchers allows Future Concept Lab to move and transfer new } \\
\text { solutions across various socio-cultural and geographical contexts. }\end{array}$ & & & & $\mathrm{X}$ & & & & \\
\hline & Mediator & $\begin{array}{l}\text { Laura Polinoro Workshop supports companies operating in different } \\
\text { industries in scouting appropriate designers and providing design } \\
\text { services. In other words, it provides services by acting as a Mediator. } \\
\text { LPWK supports other companies in the identification of appropriate } \\
\text { creative resources and the facilitation of communication between } \\
\text { manufacturers and designers. LPWK indicates the resources within the } \\
\text { company needed to set up the team involved in the workshop and } \\
\text { selects the most suitable professional figures from its network of } \\
\text { experts (communication experts, designers, marketing experts, } \\
\text { journalists, photographers, etc.) to create the best possible team. }\end{array}$ & & & & & & $\mathrm{X}$ & & \\
\hline
\end{tabular}

Table 3: Examples of Unique Assets

Finally, creative KIBS show different organizational structures to valorize contributions that come from outside of the company. As previously mentioned, the literature that interprets creative KIBS as Brokers is particularly rich and developed. According to Hargadon (1998), technology brokers are those firms that span multiple markets and technology domains and innovate by brokering knowledge from where it is known to where it is not. Several scholars have investigated the distinction between brokers that provide knowledge and mediators who 
provide contacts with other actors. While the former exploit their network position to connect separated worlds, the latter introduce disconnected organizations and facilitate their coordination.

\subsection{Value appropriation strategies}

\section{$\underline{\text { Unique Asset Value Appropriation }}$}

The analysis of the eight Italian creative KIBS underlines alternative strategies that are adopted to appropriate the value of unique assets. Specifically, a group of strategies is used for Core service; in other words, this approach is focused on increasing value when providing old services to new clients. Furthermore, other groups of strategies enlarge the service portfolio: the Adjacent service approach expands the customer activity chain (Sawhney et al., 2004) and, thus, offers additional services to old clients, while the Complementary service approach adds new customer activity chains (Sawhney et al., 2004) and allows firms to enter new markets.

Several researchers believe that many KIBS require in-depth knowledge of local cultural, regulatory, and organizational issues as well as face-to-face interaction between supplier and client, which makes difficult to get in touch with new clients especially abroad (Toivonen, 2004; Miles, 2005; Corrocher et al., 2009). Literature on service companies internationalization can be divided into three traditional categories: foreign direct investments, export and domestic offices, and foreign presence through third parties (Vandermerwe and Chadwick, 1989; Sondheimer and Bargas, 1993; Roberts, 1998). Similarly to other categories of services, the first mechanism (foreign direct investments) can also be considered dominant in the case of KIBS because of the close interaction between client and provider. The second mechanism (export and domestic offices) foresees the establishment of Subsidiaries that are able to interpret peculiarities of domestic context. The model is based on the superior control that third parties provide over service delivery and quality; moreover, it 
requires fewer resources than foreign direct investments (Vandermerwe and Chadwick, 1989).

Finally the third model is based on Commecial partnerships established between creative KIBS and local partners that allow to understand local settings and lifestyles.

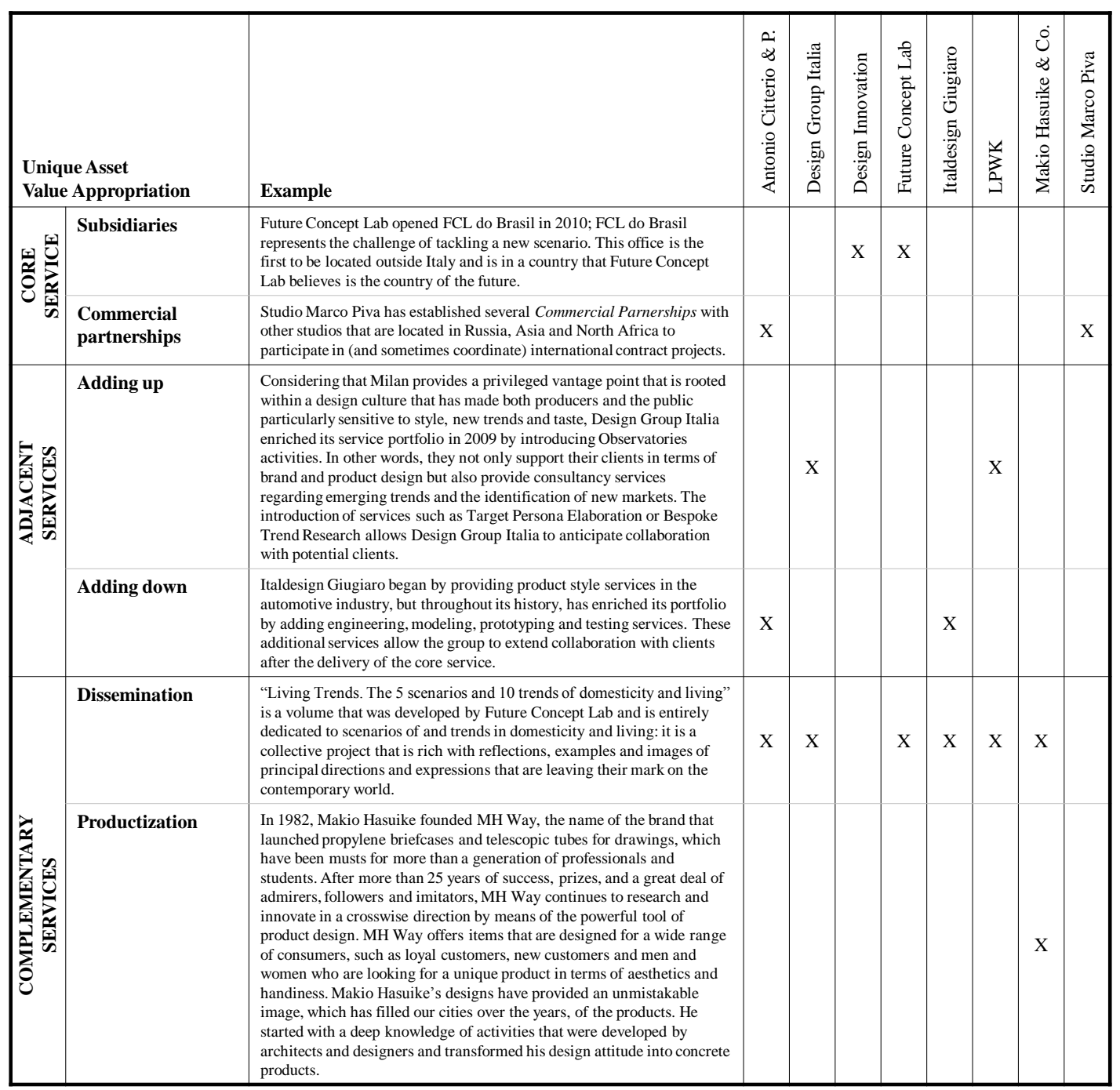

Table 4: Examples of Unique Asset Value Appropriation strategies

Adjacent services expand the customer activity chain in different directions. Adding up services represent new services that assist the client during an early stage of the customer journey, while Adding down services represent additional services that aid the client during the customer journey after the delivery of the core service. Finally, Complementary services have different natures. Future Concept Lab bases its Dissemination strategy on the publication 
of several books. In this way, they are able to communicate their unique assets to new clients with limited resources. In other words, they appropriate the value of unique assets, thus demonstrating their authoritativeness. Finally, the Productization strategy foresees the transformation of knowledge that comes from design services into products.

\section{THE RELATIONSHIP BETWEEN VALUE CREATION AND APPROPRIATION}

As highlighted, the case studies show significant differences. Three creative KIBS are characterized by turnover that is significantly higher in comparison with the other KIBS: Italdesign Giugiaro (approximately $120 \mathrm{mln} €$ ), Antonio Citterio Patricia Viel and Partners (approximately $10 \mathrm{mln} €$ ) and Makio Hauike \& Co. (approximately $3 \mathrm{mln} €$ ). Despite the fact that they provide creative services to companies that operate in different industries, they show one interesting similarity: they were able to significantly embody their unique assets; they successfully adopted strategies for formalizing and codifying their unique assets for specific technologies, archives and processes. In this way they were able to appropriate significant value potentially embedded in their assets.

Normally, creative KIBS experience difficulties in serving more clients and in offering more services, due to the importance of strong and close relationships with clients and the limited availability of skilled professionals. In many cases, creative KIBS firms consist of only the founding professionals and a limited number of close collaborators because this is the only way that creative KIBS have found to exploit their unique assets with their clients. By contrast, as detailed in the following, the three cases that show interesting connections between value creation and appropriation were able to embody their unique assets (typically, the knowledge of the founders or the key partners) and, thus, were able to exploit these assets

with more clients or more services moving from a strategy based on creative individuals to a strategy based on creative capital. In the following portion of the paper, more details on how 
these embodiment strategies have been implemented are provided, and the embodiment concept is then further discussed.

Italdesign Giugiaro was the first service company to implement a Virtual Reality Centre. Established in 1999, the Virtual Reality Centre was created for design development and has since been transformed into a working tool; software implementations and developments have become part of everyday design development and is perfectly integrated into the company workflow. The Centre is equipped with a high definition projection system $(3152 \times 1050$ pixel), 6 Barco projectors and a back-projected 21 meters square wall and is among the most advanced virtual reality centers in Europe. The methods that Italdesign Giugiaro uses for designing and engineering, structural modeling and simulation testing are continuously upgraded. The Virtual Reality Centre represents the embodiment of unique methodologies and approaches that Italdesign Giugiaro has adopted. In other words this unique asset represents a significant component of the creative capital exploited by Italdesign Giugiaro in order to grow and reach a turnover of $120 \mathrm{mln} €$ in 2009 and 900 employees.

In 1972, Antonio Citterio opened his studio, where he started his architectural and interior design business. Between 1987 and 1996, he worked in association with Terry Dwan; in 1999, in collaboration with Patricia Viel, he founded the studio "Antonio Citterio and Partners", a multidisciplinary practice for architectural design, industrial design and graphics. Progressively, the studio embedded knowledge of specific use contexts (e.g., house, hotel, resort, office) rather than specific products. This progressive embodiment of knowledge has been achieved mainly through databases, archives and the training and coaching of younger professionals. This strategy allowed the studio to enrich the creative capital obtaining holistic projects and developing a reputation as lifestyles experts.

As shown in Table 4, Makio Hasuike founded MH Way in 1982. Among other successful products, this firm launched the propylene briefcase and telescopic tubes for drawings, which have been musts for more than a generation of professionals and students. Hasuike embodied 
his personal experiences in design and architectural projects in a new brand. In other words, he exploited his empathy and knowledge to move not only from the user perspective to the designer perspective but also from the designer perspective to the manufacturer one. He was able to embed his knowledge and experience of a specific sectors in a distinctive commercial brand identity.

Throughout their history, the three creative KIBS that show higher turnover have demonstrated the capability to enrich the Unique Asset Development phase with a series of activities that we can define as Unique Asset Embodiment strategies: through these activities, creative KIBS formalize and codify the assets that differentiate their offering, which allows them to partially overcome the problems of limited scale economies and, consequently, improve the potentialities for value appropriation (see Figure 3).

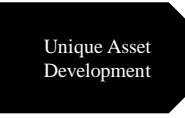

Unique Asset
Development
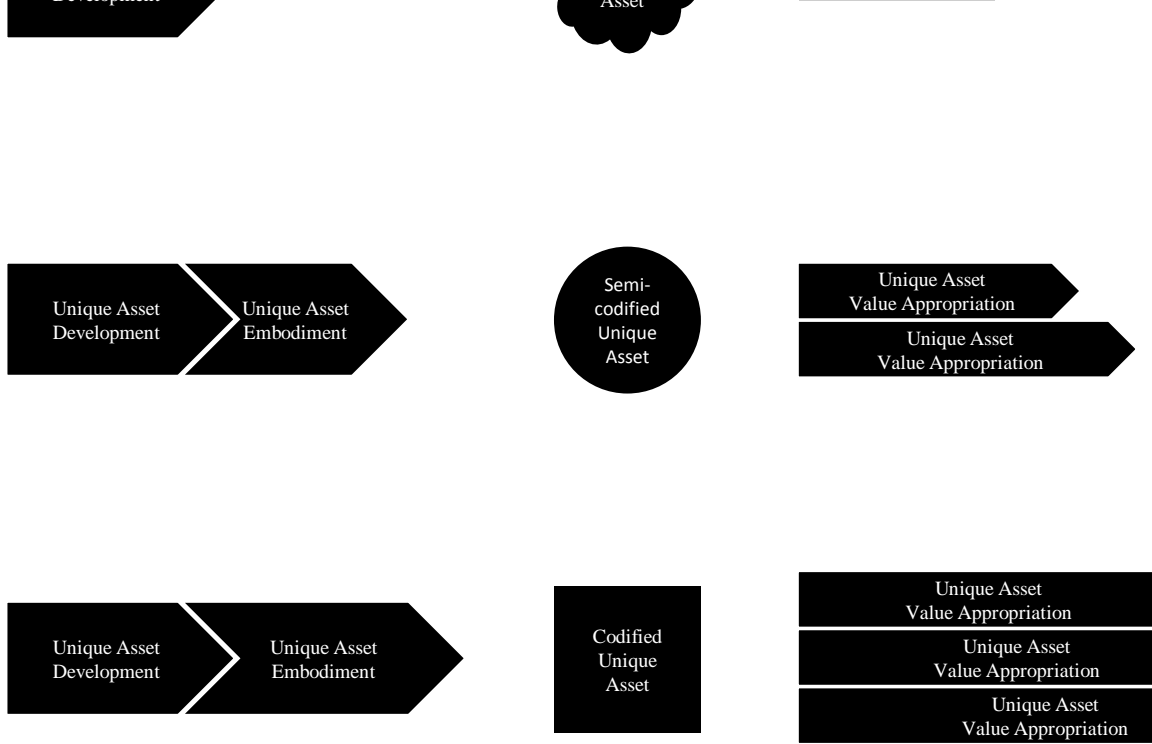

Figure 3: The impacts of Unique Asset Embodiment on potentialities of Unique Asset Value Appropriation 
The capability to embody the creative value in Unique Assets provides two significant advantages. First, the embodiment of unique assets increases the possibility of extracting more value through the adoption of the same value appropriation strategy (as shown by the length of the black arrows). For instance, Giugiaro's Virtual Reality Centre allows the firm to reduce development costs while at the same time attract clients who are interested in peculiar and advanced methodology and tools. Thanks to this Unique Asset, Italdesign Giugiaro was able to approach both new clients in the automotive industry and new markets such as transportation (train, yachts, etc.) and industrial design (white goods, small appliances, etc.) Second, the embodiment enables the adoption of specific value appropriation strategies (as shown by the number of the black arrows): in particular, in our sample, the strategies based on Adding down and Productization are adopted only by the three creative KIBS that were able to embody their unique assets. Italdesign Giugiaro began by providing product style services in the automotive industry, but throughout its history, has enriched its portfolio by adding engineering, modeling, prototyping and testing services. These additional services allow the group to extend collaboration with clients after the delivery of the core service (Adding down). As previously mentioned in 1982, Makio Hasuike founded MH Way, a company that launched very successful products for more than a generation of professionals and students. He started with a deep knowledge of activities that were developed by architects and designers and transformed his design attitude into concrete products (Productization).

Comparing the three creative KIBS that were able to embody their unique assets with the other case studies two further observations emerge. First, it appears that technical knowledge domains facilitate the embodiment process: especially Italdesign Giugiaro and Makio Hasuike \& Co. operate in creative industries where the technical knowledge is particularly relevant. On the contrary Design Innovation, Future Concept Lab and LPWK mainly deal with sociocultural knowledge where the embodiment seems to be more complex. Second it seems that the embodiment process requires various years. The three KIBS that were able to better 
embody their unique assets were founded several years ago and needed years to develop their value appropriation strategies. In particular Italdesign Giugiaro and Makio Hasuike \& Co. were founded in 1968 and while Antonio Citterio Patricia Viel and Partners was founded more recently in 1999, Antonio Citterio opened his studio in 1972. This evidence suggests that the embodiment process requires the sedimentation of creative knowledge in order to be transformed in creative capital; the embodiment seems to be more the results of research and experimentation processes than the result of intuitions.

\section{CONCLUSIONS AND IMPLICATIONS}

In the increasingly knowledge-based economy, KIBS, and in particular, creative KIBS, can play a pivotal role in both supporting other industries and operating as industries in themselves. Despite their growing importance and their peculiarities, these firms have received limited attention in terms of value creation and appropriation. According to resourcebased view theories, we have conducted a study based on 8 case studies of creative KIBS to identify and analyze value creation and appropriation strategies adopted by creative KIBS. On the basis of a theoretical framework derived from the literature and based on three pillars (Unique Assets Development, Unique Assets and Unique Assets Value Appropriation), we propose a taxonomy of value creation and appropriation strategies adopted by creative KIBS based on 4 categories of Unique Assets Development (Trend analyses, Meta-projects, Binding projects, Pioneering projects), 6 categories of Unique Assets (Superstar, Brand, Expertise, Methodology, Broker, Mediator) and 6 categories of Unique Assets Value Appropriation (Subsidiaries, Commercial partnerships, Adding up, Adding down, Dissemination, Productization). We believe that the taxonomy can provide relevant insights for managers that are looking for new strategies in order to enrich the business model of creative KIBS. 
Furthermore, we highlight the importance of Unique Asset Embodiment strategies, i.e., the importance of strategies for formalizing and codifying unique assets in specific technologies, archives, processes and even products. We show that the three largest firms of our sample were able to embody their unique assets (typically, the knowledge of the founders or the key partners) and, thus, were able to exploit these assets with more clients or more services. Specifically the embodiment of their assets allowed i) to extract more value from already adopted value appropriation strategies and ii) to adopt specific value appropriation strategies such as Adding down and Productization. While we acknowledge that the themes of knowledge codification and the differences between tacit and codified knowledge is not new (see, for instance, Penrose, 1959; Polanyi 1962; Harvey and McMeekin, 2007), we have not focused on the importance of tacit knowledge, as the majority of the literature has, but on the importance of codified knowledge, and in particular, on the codification (embodiment) process. We have referred to "embodiment strategies" and not to "codification processes" because, as shown, the results are not simply tangible products or artifacts that can be easily copied by competitors - the main limitation of codified knowledge - but remain complex sets of tools and knowledge that are difficult to separate from firms adopting them. We have shown the importance of specific strategies, and in particular, embodiment strategies, in the context of creative KIBS. The foundation and start-up phase of these firms is not difficult due to the limited costs involved, but few firms are able to move from creative individuals to creative capital. We argued that Unique Asset Embodiment strategies are fundamental to support this shift because of the possibility they offer of partially reaching economies of scale in this sector.

We also acknowledge that other value embodiment and appropriation strategies exist. This issue could prove to be an interesting topic for further studies. For instance, a pivotal and widely studied case that can be considered is that of Intellectual Property Protection strategies. However, as is well known, this strategy is more difficult to implement in creative 
KIBS and in KIBS in general due to the mainly non-technological basis of their innovations. This consideration leads to another interesting avenue of research that can further the results of our study: the examination of the reliability of the identified strategies and the presence of other strategies in other KIBS sectors. In fact, we believe that the knowledge capital developed and exploited by other famous KIBS, such as large consulting firms (e.g., McKinsey, Deloitte, Accenture, Bain, and BCG) can, in part, be viewed as the result of the capacity of embedding the knowledge of first funders and professionals in specific knowledge bases, relationships, practices and processes. 


\section{REFERENCES}

1. Barney J (1991). Firm Resources and Sustained Competitive Advantage. Journal of Management, Vol. 17, No. 1, Pp. 99-120.

2. Colombo G, Dell'Era C and Frattini F (2011). New Product Development (NPD) service suppliers in Open Innovation practices: processes and organization for knowledge exchange and integration. International Journal of Innovation Management, vol. 15, No. 1, Pp. 165-204.

3. Czarnitzki D and Spielkamp A (2000). Business services in Germany: bridges for innovation. ZEW discussion paper, No. 00-52. Mannheim.

4. Dell'Era C, Marchesi A and Verganti R (2008). Linguistic Network Configurations: management of innovation in design-intensive firms. International Journal of Innovation Management, Vol. 12, No. 1, Pp. 1-19.

5. Dell'Era C and Verganti R (2010). Collaborative Strategies in Design-Intensive Industries: Knowledge Diversity and Innovation. Long Range Planning, Vol. 43, Pp. $123-141$.

6. Durgee JF (2006). Freedom of superstar designers? Lessons from art history. Design Management Review, Vol. 17, No. 3, Pp. 29-34.

7. Eisenhardt KM (1989). Building theories from case study research. Academy of Management Review, 14, 532-550.

8. Eisenhardt, K.M. and Graebner, M.E. (2007). Theory building from cases: opportunities and challenges, Academy of Management Journal, 50, 1, 25-32.

9. European Commission, 2010, GREEN PAPER- Unlocking the potential of cultural and creative industries. 
10. Florida R and Goodnight J (2005). Managing for Creativity. Harvard Business Review, July-August.

11. Gierke M; Hansen JG and Turner R (2002). Wise counsel: A trinity of perspectives on the business value of design. Design Management Journal, Vol. 13, No. 1, Pp. 10.

12. Groysberg, B, Lee, L-E, (2009). Hiring Stars and Their Colleagues: Exploration and Exploitation in Professional Service Firms. Organization Science Vol. 20, No. 4, JulyAugust 2009, pp. 740-758.

13. Gupta, A.K., Smith, K.G. e Shalley, C.E. 2006. The Interplay Between Exploration And Exploitation. Academy of Management Journal 49, 4: pp. 693-706.

14. Hargadon AB (1998). Firms as knowledge brokers: lessons in pursuing continuous innovation. California Management Review, Vol. 40, No. 3, Pp. 209-227.

15. Lepak, D.P., Smith, K.G. e Taylor, M.S. 2007. Value Creation and Value Capture: A Multilevel Perspective. Academy of Management Review 32: pp. 180-194.

16. March, J.G. 1991. Exploration and Exploitation in Organizational Learning. Organization Science Vol. 2, No. 1.

17. Miles, I. (2007). Research and development (R\&D) beyond manufacturing: the strange case of services R\&D. $R \& D$ Management, 37, 3, 249-268.

18. Mizik, N. e Jacobson, R. 2003. Trading Off Between Value Creation and Value Appropriation: The Financial Implications of Shifts in Strategic Emphasis. Journal of Marketing 67: pp. 63-76.

19. Muller, E., Zenker, A., (2001). Business services as actors of knowledge transformation: the role of KIBS in regional and national innovation system, Research Policy, 30, 1501-1516.

20. NSF, Science and Engineering Indicators 2010. 
21. Oke, A. (2007). Innovation types and innovation management practices in service companies. International Journal of Operations \& Production Management. 27, 6, 564-587.

22. Ravasi D and Lojacono G (2005). Managing design and designers for strategic renewal. Long Range Planning, Vol. 35,Pp. 51-77.

23. Sawhney M, Balasubramanian S and Krishnan VV (2004). Creating growth with services. Sloan Management Review, Vol. 45, No. 2.

24. Starbuck S (1992). Learning by Knowledge-Intensive Firms. Journal of Management Studies, Vol. 29, No. 6

25. Teece, D.J., 2007. Explicating Dynamic Capabilities: The Nature And Microfoundations Of (Sustainable) Enterprise Performance. Strategic Management Journal 28: pp.1319-1350.

26. Teece, D.J., 1986. Profiting From Technological Innovation: Implications For Integration, Collaboration, Licensing And Public Policy. Research Policy 15: pp.285305.

27. Van Looy B., Landoni, P., Callaert J., Van Pottelsberghe B., Sapsalis E., Debackere K., (2011) "Entrepreneurial Effectiveness of European Universities: An empirical assessment of antecedents and trade-offs." Research Policy, Vol. 40, pp. 553-564

28. Vandermerwe S and Chadwick M (1989). The internationalisation of services. The Service Industries Journal, Vol. 9, No. 1, Pp. 79-93.

29. Verganti, R. (2009) Design Driven Innovation - Changing the Rules of Competition by Radically Innovating what Things Mean. Harvard Business Press, Boston, MA.

30. Wernerfelt B (1984). A Resource-Based view of the Firm. Strategic Management Journal; Vol. 5, No. 2, Pp. 171-180. 
31. Windrum P and Tomlinson M (1999). Knowledge-intensive services and international competitiveness: a four country comparison, Technology Analysis \& Strategic Management, Vol. 11, No. 3, Pp. 391-405.

32. Yin RK (1984). Case Study Research, Design and Methods. London: Sage Publications. 